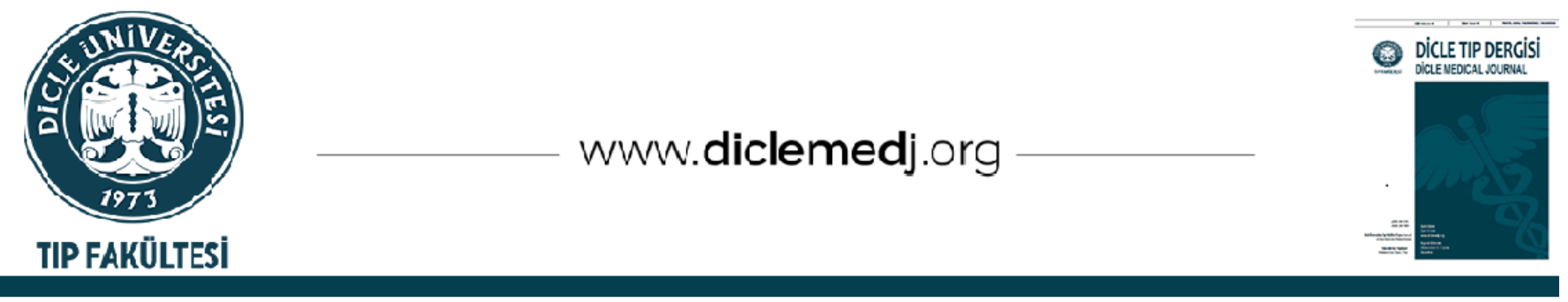

Original Article / Özgün Araştırma

\title{
The benefit of surgery on survival for patients with stage 1 and 2 malignant pleural mesothelioma
}

\author{
Birol Ocak ${ }^{i}{ }_{1}$, Ahmet Bilgehan Şahin ${ }^{i}{ }_{1}$, Bahar Dakiki ${ }^{2}$, Hikmet Utku Odman ${ }^{2}$, Sibel Oyucu \\ Orhan ${ }^{D}$ 1, Adem Deligönül ${ }^{D}$ 1, Hüseyin Melek iD 3, Erdem Çubukçu iD 1, Türkkan Evrensel iD 1
}

1 Department of Medical Oncology, Faculty of Medicine, Bursa Uludag University, Bursa, Turkey

2 Department of Internal Medicine, Faculty of Medicine, Bursa Uludag University, Bursa, Turkey

3 Department of Thoracic Surgery, Faculty of Medicine, Bursa Uludag University, Bursa, Turkey

Received: 11.08.2020; Revised: 26.10.2020; Accepted: 02.11.2020

\begin{abstract}
Objective: Malignant mesothelioma is a rare and aggressive cancer. We aim to report our experience of stage 1 and 2 malign pleural mesothelioma (MPM) and investigate the prognostic factors.

Methods: We retrospectively reviewed 37 patients with clinical stage 1 and 2 MPM in our center and examined radiological findings, demographic characteristics, treatment modalities, survival, and recurrence.

Results: Eighteen of the 37 patients were male, and the mean age of the patients was $59.0 \pm 11.2$ years. Thirty patients had stage $1 \mathrm{MPM}$, and 7 patients had stage 2. Seven patients underwent surgery, and 30 patients received induction chemotherapy. Median progression-free survival (PFS) was 12.3 months (95\% confidence interval [CI], 9.4-15.1), and the median overall survival (OS) was 24.3 months (95\% CI, 15.8-32.8). In multivariate analysis, while gender and surgery had a statistically significant effect on PFS ( $p=0.01, p=0.01$, respectively), both gender and surgery did not significantly affect $\mathrm{OS}$ ( $\mathrm{p}=0.15, \mathrm{p}=0.08$, respectively). Local recurrence occurred in 28 patients, and 7 patients were presented with local recurrence and distant metastasis.
\end{abstract}

Conclusion: In our study, where the majority of patients were stage 1 and 2 , the effect of the surgery was significant.

Keywords: Chemotherapy, malign pleural mesothelioma, stage 1-2, surgery

\section{DOI: 10.5798/dicletip.850203}

Correspondence / Yazışma Adresi: Birol Ocak, Department of Medical Oncology, Faculty of Medicine, Bursa Uludag University, Nilufer 16059, Bursa, Turkey; e-mail: birol08ocak@gmail.com 


\section{Evre 1-2 Malign Plevral Mezotelyoma Hastalarında Sağkalıma Cerrahinin Katkısı}

\section{Öz}

Amaç: Malign plevral mezotelyoma nadir görülen, agresif seyirli bir kanserdir. Bu çalışmamızda, evre1-2 malign plevral mezotelyomada prognostik faktörleri araştırmayı ve deneyimlerimizi sunmayı amaçladık.

Yöntemler: Merkezimizde evre 1 ve 2 MPM olan 37 hastanın radyolojik bulgularını, demografik özelliklerini, tedavi yöntemlerini, sağkalımını ve nüksünü retrospektif olarak inceledik.

Bulgular: 37 hastanın 18'i erkekti ve hastaların yaş ortalaması 59,0 0 11,2 yıldı. Evre-1 30 hasta, evre-2 7 hasta vardı. 7 hasta opere oldu, 30 hasta ise indüksiyon kemoterapisi aldı. Medyan progresyonsuz sağkalım 12,3 ay (\%95 CI, 9,4-15,1) ve medyan genel sağ kalım 24,3 ay (\%95 CI, 15,8-32,8) olarak bulundu. Çok değişkenli analizde, cinsiyet ve cerrahinin hastalıksız sağ kalım üzerinde istatistiksel olarak anlamlı etkisi saptanırken (sırasıyla $\mathrm{p}=0,01, \mathrm{p}=0,01$ ), hem cinsiyet hem de cerrahi genel sağ kalımı anlamlı olarak etkilemedi (sırasıyla p=0,15, p=0,08). 28 hastada lokal nüks, 7 hastada lokal nüks ve uzak metastaz saptandl.

Sonuç: Cerrahinin etkisi, evre 1-2 hastaların çoğunlukta olduğu çalışmamızda anlamlı olarak bulundu.

Anahtar Kelimeler: Kemoterapi, malign plevral mezotelyoma, evre 1-2, cerrahi.

\section{INTRODUCTION}

Malignant mesothelioma originates from mesothelial cells of the pleura, peritoneum, pericardium, or tunica vaginalis. Asbestos and erionite are the most significant risk factors associated with the development of malignant pleural mesothelioma (MPM) ${ }^{1}$. There are three histologic types of MPM: epithelioid, sarcomatoid, and biphasic mesothelioma. The epithelioid variant is the most common, accounting for about $60 \%$ of all mesotheliomas ${ }^{2}$.

The contrast-enhanced thorax tomography and 18-Fluorodeoxyglucose positron emission tomography-computed tomography are used to identify pleural abnormalities, pleural effusion, parenchymal lesions, and the stage of the disease, guide pleural biopsy, and predict survival $^{3}$. Video-assisted thoracoscopic surgery (VATS) or an open thoracotomy provides sufficient tissue for diagnosis 4 .

The purpose of staging in MPM is to identify patients who may benefit from surgical resection. If a patient with clinical stage 1 to $3 \mathrm{~A}$ is eligible for surgery after multidisciplinary evaluation, a pleurectomy with decortication (P/D) or extrapleural pneumonectomy (EPP) can be performed. If the patient is ineligible for surgery, re-evaluation after induction chemotherapy is recommended. After $\mathrm{P} / \mathrm{D}$, chemotherapy is administered, and radiotherapy can be applied. EPP is followed by sequential chemotherapy and hemithoracic radiation ${ }^{5}$.

In the present study, we aimed to investigate the factors affecting survival, chemotherapy regimens, and recurrence patterns of the disease in patients with clinical stage 1 and 2 MPM in our center.

\section{METHODS}

Thirty-seven patients diagnosed as stages 1 and 2 MPM in the Department of Medical Oncology, Faculty of Medicine, Bursa Uludag University between 2010 and 2018 were included in this retrospective study. Non-invasive methods, such as thorax computed tomography, positron emission tomography/computed tomography, and invasive techniques, such as VATS, were used in the clinical staging of the patients. All patients were evaluated at the multidisciplinary thoracic oncology council. The data about 
patient complaints at admission, radiological findings, demographic characteristics, smoking habits, family histories, tumor localizations, diagnostic methods, histopathological features, induction chemotherapy, types of operation, post-operative maintenance chemotherapy, and recurrence were collected from electronic files of the patients. The patients were staged using MPM TNM staging, according to the AJCC 8th edition. Our study included the patients older than 18 years, diagnosed with stage 1 and 2 MPM, and followed up by our clinic. Patients with incomplete data about the stage at diagnosis, laboratory results were excluded from the study. Cisplatin $75 \mathrm{mg} / \mathrm{m} 2$ plus pemetrexed $500 \mathrm{mg} / \mathrm{m} 2$ on day 1 in every 21 days; carboplatin (area under the curve 5 $\mathrm{mg} / \mathrm{mL}$ per min) plus pemetrexed $500 \mathrm{mg} / \mathrm{m} 2$ on day 1 in every 21 days; pemetrexed $500 \mathrm{mg}$ $\mathrm{m} 2$ on day 1 plus gemcitabine $1250 \mathrm{mg} / \mathrm{m} 2$ on first and eighth days in every 21 days were used as induction chemotherapy. The induction chemotherapies were selected considering the patients' ages and comorbidities. Folic acid and vitamin B12 replacements were given to patients who received pemetrexed. Pleurectomy with decortication (P/D) or extrapleural pneumonectomy (EPP) operations were performed on patients scheduled for surgery. Cisplatin was administered at doses of $50-75 \mathrm{mg} / \mathrm{m} 2$ in Hyperthermic intra-thoracic chemotherapy (HITHOC). In radiotherapy, 40 Gy of radiation was performed. This study was approved by the clinical research ethics committee of Bursa Uludag University (Decision No: 2019-19/20).

\section{Outcomes}

Progression-free survival (PFS) was defined as the time from the administration of chemotherapy or surgery, whichever was performed first to the recurrence of tumor or death. Overall survival (OS) was determined from the time of diagnosis until death from any cause.

\section{Statistical Analysis}

Continuous variables were expressed by mean and median values, and categorical variables were expressed by frequency and corresponding percentage values. Survival analysis was calculated using the Kaplan-Meier method. The univariate effects of gender, age, surgery, induction chemotherapy, and radiotherapy on survival were investigated by the log-rank test. Enter model in cox regression analysis was used with parameters having a pvalue below 0.2 to determine independent factors. The data were statistically processed using IBM SPSS version 22 software. In all statistical analyses, $\mathrm{p}<0.05$ was accepted as statistically significant for the results.

\section{RESULTS}

The clinical and demographic characteristics of the patients are given in Table 1. Eighteen of the 37 patients were male, and the mean age of the patients was $59.0 \pm 11.2$ years. Among the patients' complaints, 31 (83.8\%) had dyspnea, 5 (13.5\%) had chest pain, 5 (13.5\%) had a cough, and 1 patient (\%2.7) had weight loss. The radiological evaluation of the patients at admission detected 27 (73\%) with pleural effusion and $13 \quad(35.1 \%)$ with pleural involvement (plaque). After clinical evaluation, 30 patients had stage 1 , and 7 patients had stage 2 . The disease was located in the right lung in 22 patients. Thirty-four patients had epithelioid, and 3 had biphasic histopathology. 
Table I: The clinical and demographic characteristics of the patients

\begin{tabular}{|c|c|c|c|}
\hline \multicolumn{2}{|l|}{ Parameter } & \multicolumn{2}{|c|}{$\mathrm{N}(\%)$} \\
\hline \multicolumn{2}{|l|}{ Age (mean \pm SD) (years) } & \multicolumn{2}{|c|}{$59.0 \pm 11.2$} \\
\hline \multicolumn{2}{|l|}{ Gender } & \multicolumn{2}{|c|}{$18 / 19$} \\
\hline \multicolumn{2}{|l|}{ (Male/Female) $(n, \%)$} & \multicolumn{2}{|c|}{$(48.6 / 51.4)$} \\
\hline \multirow{7}{*}{ Place of birth (Region) } & Marmara & 17 & (46) \\
\hline & Eastern Anatolia & 6 & $(16.2)$ \\
\hline & Central Anatolia & 4 & $(10.8)$ \\
\hline & Aegean & 3 & (8.1) \\
\hline & Black Sea & 3 & $(8.1)$ \\
\hline & Southeast & 1 & $(2.7)$ \\
\hline & Missed data & 3 & $(8.1)$ \\
\hline \multirow{4}{*}{ Complaints at admission } & Dyspnea & 31 & (72.1) \\
\hline & Cough & 5 & $(11.6)$ \\
\hline & Chest pain & 6 & $(13.9)$ \\
\hline & Weight loss & 1 & $(2.4)$ \\
\hline \multirow{2}{*}{ Radiological findings } & Pleural effusion & 27 & $(67.5)$ \\
\hline & Pleural involvement(plaque) & 13 & $(32.5)$ \\
\hline \multirow{3}{*}{ Smoking habit } & Smoker & 6 & $(16.2)$ \\
\hline & Non-smoker & 7 & (18.9) \\
\hline & Missed data & 24 & $(64.9)$ \\
\hline \multirow{3}{*}{ Asbestos Exposure } & Present & 17 & $(46)$ \\
\hline & Absent & 13 & (35) \\
\hline & Missed data & 7 & (19) \\
\hline \multirow{2}{*}{ Tumor Localization } & Right & 22 & $(59.5)$ \\
\hline & Left & 15 & $(40.5)$ \\
\hline \multirow{3}{*}{ Diagnostic Method } & VATS & 25 & (67.6) \\
\hline & Tru-Cut & 10 & $(27.0)$ \\
\hline & Missed data & 2 & $(5.4)$ \\
\hline \multirow{2}{*}{ Histopathology } & Epithelioid & 34 & $(91.9)$ \\
\hline & Biphasic & 3 & $(8.1)$ \\
\hline \multirow{2}{*}{ Stage at diagnosis } & Stage 1 & 30 & $\begin{array}{l}(81.1) \\
\end{array}$ \\
\hline & Stage 2 & 7 & $(18.9)$ \\
\hline \multirow{2}{*}{ Induction Chemotherapy } & Yes & 30 & $(81.1)$ \\
\hline & No & 7 & $(18.9)$ \\
\hline \multirow{3}{*}{$\begin{array}{l}\text { Induction } \\
\text { Regimen }\end{array}$} & Cisplatin + Pemetrexed & 19 & $(63.4)$ \\
\hline & Carboplatin + Pemetrexed & 10 & (33.3) \\
\hline & Gemcitabine + Pemetrexed & 1 & $(3.3)$ \\
\hline \multicolumn{2}{|l|}{ Induction Chemotherapy Cycles (median) (min-max) } & 4.5 & $(2-7)$ \\
\hline \multirow{4}{*}{ Treatment Modalities } & S without IC plus post-operative $\pm \mathrm{CT} \pm \mathrm{RT}$ & 7 & $(18.9)$ \\
\hline & S after IC plus post-operative $\pm \mathrm{CT} \pm \mathrm{RT}$ & 22 & $(59.5)$ \\
\hline & Progression after IC & 2 & $(5.4)$ \\
\hline & CT without $\mathrm{S}$ after IC & 6 & $(16.2)$ \\
\hline
\end{tabular}

Abbreviations: S, surgery; IC, induction chemotherapy; CT, chemotherapy; RT, radiotherapy. 
Seven patients underwent surgery without induction chemotherapy. They all received chemotherapy with a median of 5 cycles (range, 3-6) in the post-operative period. Thirty patients received induction chemotherapy, of which the median number of cycles was 4 (range, 2-7). The induction chemotherapy regimens follow as cisplatin-pemetrexed in 19 patients, carboplatin-pemetrexed in ten patients, and gemcitabine-pemetrexed in one patient. Twenty-two patients underwent surgery after induction chemotherapy. Six patients continued with chemotherapy after induction without surgery since they were not eligible for surgery. Two patients had progression after induction chemotherapy. Of 29 patients who had surgery, 25 had stage 1 disease and 4 had stage 2 disease. In total, four patients underwent EPP operation, and 25 patients underwent $\mathrm{P} / \mathrm{D}$ surgery.

Median PFS was 12.3 months (95\% confidence interval [CI], 9.4-15.1), and the median OS was 24.3 months (95\% CI,15.8-32.8) (Figure 1). Disease progression was observed in all patients except for two patients. Of the 37 patients, 32 died.
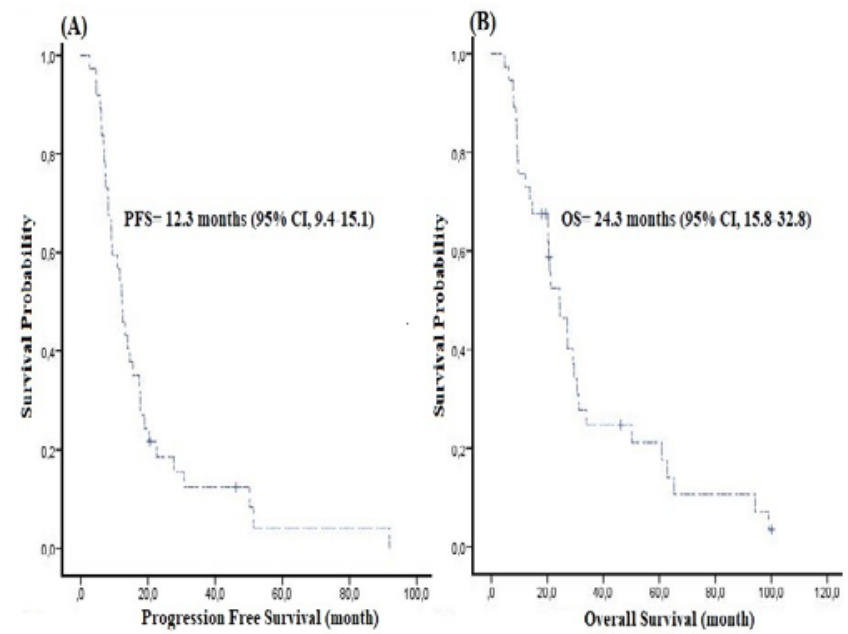

Figure 1. Progression-free survival (PFS) (A) and overall survival (OS) (B) for the patients.

Factors affecting the PFS, gender, surgery, and age were included in the multivariate analysis (Table 2). Multivariate analysis revealed that gender ( $\mathrm{HR}$ 3.94 CI, 1.72-9.03, $\mathrm{p}=0.01$ ) and surgery (HR 7.18 CI, 2.33-22.02, $\mathrm{p}=0.01$ ) were independent factors affecting PFS. The diseasefree survival curve for patients according to surgery is presented in Figure 2A.

Table II: Results of Cox regression multivariate analysis of the independent factors for Progression-free survival and overall survival

\begin{tabular}{|c|c|c|c|c|c|}
\hline \multicolumn{6}{|l|}{ Progression-free survival } \\
\hline Factor & Wald & p-value & HR & $\begin{array}{r}95 \% \\
\text { Lower lin }\end{array}$ & $\begin{array}{l}\text { dence } \\
\text { al } \\
\text { pper limit }\end{array}$ \\
\hline \multicolumn{6}{|l|}{ Age } \\
\hline$\leq 65$ & - & - & 1 & - & - \\
\hline$>65$ & 0.55 & 0.815 & 0.89 & 0.34 & 2.3 \\
\hline \multicolumn{6}{|l|}{ Gender } \\
\hline Female (RC) & - & - & 1 & - & - \\
\hline Male & 10.53 & 0.01 & 3.94 & 1.72 & 9.03 \\
\hline \multicolumn{6}{|l|}{ Surgery } \\
\hline Done (RC) & - & - & 1 & - & - \\
\hline Not Done & 11.90 & 0.01 & 7.18 & 2.33 & 22.02 \\
\hline \multicolumn{6}{|l|}{ Overall Survival } \\
\hline \multirow[t]{2}{*}{ Factor } & \multirow[t]{2}{*}{ Wald } & $p$-value & \multirow[t]{2}{*}{ HR } & $\begin{array}{r}95 \% \\
\text { Ir }\end{array}$ & $\begin{array}{l}\text { dence } \\
\text { al }\end{array}$ \\
\hline & & & & Lower lin & pper limit \\
\hline \multicolumn{6}{|l|}{ Gender } \\
\hline Female (RC) & - & - & 1 & - & - \\
\hline Male & 2.07 & 0.15 & 1.75 & 0.81 & 3.77 \\
\hline \multicolumn{6}{|l|}{ Surgery } \\
\hline Done $(\mathrm{RC})$ & - & - & 1 & - & - \\
\hline Not Done & 3.02 & 0.08 & 2.19 & 0.90 & 5.29 \\
\hline \multicolumn{6}{|c|}{ Abbreviations: $H R$, hazard ratio; $R C$, reference category. } \\
\hline \multicolumn{6}{|c|}{$\begin{array}{l}\text { In Cox regression analysis, which was } \\
\text { performed after the univariate analysis, gender } \\
\text { and surgery did not have a statistically } \\
\text { significant effect in OS (p=0.15 and } p=0.08 \text {, } \\
\text { respectively) (Table } 2) \text {. The } p \text {-value of the } \\
\text { surgery was within the limit of significance. The } \\
\text { overall survival curve for patients according to } \\
\text { surgery is presented in Figure } 2 \mathrm{~B} \text {. }\end{array}$} \\
\hline
\end{tabular}



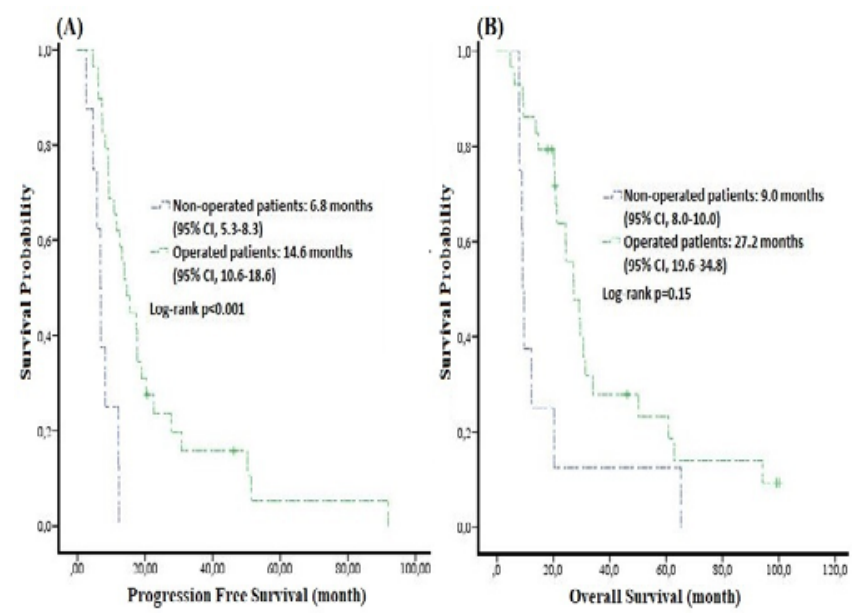

Figure 2. Progression-free survival (A) and overall survival (B) for operated and non-operated malignant pleural mesothelioma patients.

Fifteen patients who received HITHOC during surgery and 14 patients without HITHOC were evaluated with the log-rank test. There was no statistically significant difference in PFS and OS ( $p=0.241$ and $p=0.941$, respectively). In our study, no statistically significant difference was detected in the PFS and OS in patients who underwent surgery after induction chemotherapy and who were operated on without receiving induction chemotherapy ( $\mathrm{p}=0.848$ and $\mathrm{p}=0.816$, respectively).

Radiotherapy was administered to 3 patients who underwent induction chemotherapy without surgery and to 7 patients who were operated upon after induction chemotherapy. Due to chest wall invasion in 3 patients and a residual tumor in 7 patients, radiotherapy was administered with $40 \mathrm{~Gy}$.

At the time of the first recurrence, 35 of 37 patients presented with local recurrence \pm distant metastasis. Among 35 patients, local recurrence occurred in 28 patients, and 7 patients were presented with local recurrences and distant metastasis. Local recurrence sites for 35 patients included: pleural thickening (60\%), mediastinal lymph node (40\%) patients, pleural effusion (40\%), pericardial involvement (11.4\%), and invasion of the chest wall (5.7\%) (Table 3). Distant recurrence sites for 7 patients included: bone metastases (28.5\%), adrenal metastases (28.5\%), intra-abdominal lymphadenopathy (14.2\%), lung parenchyma $(14.2 \%)$ and peritoneal involvement (14.2\%) (Table 3).

Table III: Local recurrence and distant metastasis site

\begin{tabular}{|lc|}
\hline \hline Sites of local recurrence & $\mathbf{n}(\%)$ \\
\hline \hline Pleural thickening & $21(60 \%)$ \\
Mediastinal lymph node & $14(40 \%)$ \\
Pericardial involvement & $14(40 \%)$ \\
Chest wall invasion & $4(11.4 \%)$ \\
\hline \hline Sites of distant metastasis & $2(5.7 \%)$ \\
\hline Bone & $\mathbf{n}(\%)$ \\
Adrenal & $2(28.5 \%)$ \\
Abdominal lymphadenopathy & $2(28.5 \%)$ \\
Lung parenchyma & $1(14.2 \%)$ \\
\hline \hline
\end{tabular}

Table IV: Chemotherapy adverse effects

\begin{tabular}{|lcccc|}
\hline \hline Adverse Effects & Grade 1 & Grade 2 & Grade 3 & Grade 4 \\
& N (\%) & N (\%) & N (\%) & N (\%) \\
\hline \hline Anaemia & $3(8.1 \%)$ & $2(5.4 \%)$ & $1(2.7 \%)$ & - \\
Thrombocytopenia & $2(5.4 \%)$ & $1(2.7 \%)$ & $1(2.7 \%)$ & - \\
Neutropenia & $2(5.4 \%)$ & $3(8.1 \%)$ & $1(2.7 \%)$ & $1(2.7 \%)$ \\
Liver Enzyme & $2(5.4 \%)$ & $1(2.7 \%)$ & $2(5.4 \%)$ & - \\
Elevation & $1(2.7 \%)$ & $1(2.7 \%)$ & - & - \\
Acute Kidney Injury & $6(16.2 \%)$ & $2(5.4 \%)$ & $1(2.7 \%)$ & - \\
Weakness & $4(10.8 \%)$ & $2(5.4 \%)$ & - & - \\
Nausea/Vomiting & & & & - \\
\hline \hline
\end{tabular}

Adverse events of first-line chemotherapies administered to MPM patients in our study are presented in Table 4. The most commonly encountered grade 1 adverse event was 
weakness, grade 2 adverse event neutropenia, and grade 3-4 adverse event liver enzyme elevation.

\section{DISCUSSION}

Two significant studies evaluating early-stage pleural mesothelioma patients, reported by Krug et al. ${ }^{6}$ and Weder et al. 7 , included patients with stages 1-3 MPM. In both studies, patients underwent surgery after induction chemotherapy, and stage 3 patients were the most common, while fewer stage 1 patients were included. In our study, the majority were stage 1 patients. In the initial evaluation, we sought to answer if there was a difference in treatment approaches for stage 1 and 2 MPM patients who were not eligible for surgery.

In our study, multivariate analysis revealed that patients who underwent surgery in the early stages of the disease had a significant difference in PFS compared to patients who had not been operated on; however, no significant difference in OS was observed $(\mathrm{p}=0.01$ and $\mathrm{p}=0.08$, respectively). In the Krug et al. study ${ }^{6}$, the median survival of all patients was 16.8 months, while the median survival of the patients who underwent surgery was 21.9 months. In the Avijit Datta et al. study, the median OS was 6.1 months in patients non-operated for pleural mesothelioma, and the median OS was found to be 12.6 months in patients operated for mesothelioma ${ }^{8}$. Our study and previous studies reinforce the importance of surgery in pleural mesothelioma. Patients should be evaluated for surgery at the time of diagnosis and after induction chemotherapy, and eligible ones should be referred to surgery.

Pleural mesothelioma is more common in men than in women'. In our study, female patients were the majority. In the multivariate analysis that investigated the effect of gender on PFS and OS in our study, gender had a statistically significant effect in PFS ( $\mathrm{p}=0.01)$, but it did not have a statistically significant effect in OS $(\mathrm{p}=0.15)$. In the study ${ }^{9}$ by Taioli et al., despite the similar basic features for both genders, 5year overall survival was found to be $13.4 \%$ in women and $4.5 \%$ in men $(\mathrm{p}<0.0001)$.

Studies and international guidelines recommend induction chemotherapy in the first evaluation for stages 1 to $3 \mathrm{~A}$ of the disease if surgery is not suitable ${ }^{6-8}$. The survival benefit of the induction chemotherapy in PFS and OS was not detected in our study. Previous studies corroborate these findings. For example, in the Espinoza et al. study ${ }^{10}$, comparing neoadjuvant and adjuvant chemotherapy for resectable malignant pleural mesothelioma, the timing of chemotherapy did not affect survival even when age, race, histology, clinical stage, comorbidity index, and radiation therapy were considered. Furthermore, in the Voigt et al. study ${ }^{11}$, which investigated the role of neoadjuvant chemotherapy in patients with resectable malignant pleural mesothelioma, similar survival data were obtained in patients who received neoadjuvant chemotherapy and in patients who underwent surgery without receiving chemotherapy.

In our study, no statistically significant difference was noticed in PFS and OS in the group of patients who underwent HITHOC during the operation $(\mathrm{p}=0.241$ and $\mathrm{p}=0.941$, respectively). There is a limited number of randomized controlled trials about the effectiveness of HITHOC in pleural mesothelioma. In the Sugarbaker et al. study ${ }^{12}$, cisplatin doses of 175 to $225 \mathrm{mg} / \mathrm{m} 2$ and above have been reported to benefit survival. In our center, cisplatin is administered at lower doses than previous trials. The reason for not observing a statistical difference may be doserelated.

In the consensus recommendations of Gomez et al. ${ }^{13}$ regarding the use of radiotherapy for MPM, radiotherapy is recommended as follows: hemithoracic radiotherapy before or after EPP, adjuvant to lung-sparing procedures, or 
palliation of focal symptoms. In our study, no statistically significant difference was detected in the effect of radiotherapy on PFS and OS in the multivariate analysis. Due to chest wall invasion in 3 patients and a residual tumor in 7 patients, radiotherapy was administered.

In our study, the pattern of recurrence of stage 1-2 MPM patients revealed local recurrence in $75.6 \%$ of patients and local recurrence + distant metastasis in $18.9 \%$ of patients. The most common local recurrence was pleural thickening, and the most common distant metastasis site was bone and adrenal gland. While early-stage MPM patients progress mostly as local recurrence, local recurrence + distant organ metastasis may be observed in a small number of patients. In the literature, the studies of Krug et al. ${ }^{6}$ and Weder et al. ${ }^{7}$, which included patients who underwent surgery after induction chemotherapy, did not provide information about the disease's recurrence sites. In our study, grade 1-4 adverse effects of first-line chemotherapies were manageable. No drug-related deaths were detected in retrospective records.

\section{Limitations}

Our study was retrospective, the sample size was small, the majority of our patients were at stage 1 , with a limited number of stage 2 patients, and P/D surgery was preferred. Also, due to the low number of biphasic subtypes, no comparative statistical analysis was performed with the epithelioid subtype. Due to the retrospective nature of our study, nonlaboratory adverse effects could not be entirely reported.

\section{CONCLUSION}

Studies examining early-stage mesothelioma patients include mostly stage 3 and less frequently stages 1 and 2 patients. Therefore, decisions about the management of stages 1 and 2 of the disease emerged from studies in which the number of stage 3 patients was the majority.
In our study, where the number of stages 1 and 2 patients were the majority, the effect of the surgery was apparent. Multicenter prospective studies are needed to investigate the management of stage 1 and 2 patients and the differences compared to stage $3 \mathrm{~A}$ patients.

Ethics Committee Approval: Bursa Uludag University Clinical Research Ethics Committee granted approval for this study (date: 20.11.2019, number: 2019-19/20).

Declaration of Conflicting Interests: The authors declare that they have no conflict of interest.

Financial Disclosure: No financial support was received.

\section{REFERENCES}

1. Hiriart E, Deepe R, Wessels A. Mesothelium and Malignant Mesothelioma. J Dev Biol. 2019; 7.

2. Ali G, Bruno R, Fontanini G. The pathological and molecular diagnosis of malignant pleural mesothelioma: a literature review. J Thorac Dis. 2018; 10: 276-84.

3. Akdeniz N, Küçüköner M, Kaplan MA, et al. The Effect of Metabolic PET Parameters on Survival Outcome in Malignant Pleural Mesothelioma. Dicle Tıp Dergisi. 2020; 47: 16-23.

4. Perikleous P, Waller DA. Video assisted thoracoscopic and open chest surgery in diagnosis and treatment of malignant pleural diseases. J Vis Surg. 2017;3:85.

5. National Comprehensive Cancer Network. Malignant Pleural Mesothelioma (Version 1.2020). [https://www.nccn.org/professionals/physician_gl s/pdf/mpm.pdf]. (Access date: 05/03/2020).

6. Weder W, Stahel RA, Bernhard J, et al. Multicenter trial of neo-adjuvant chemotherapy followed by extrapleural pneumonectomy in malignant pleural mesothelioma. Ann Oncol. 2007; 18: 1196-202.

7. Krug LM, Pass HI, Rusch VW, et al. Multicenter phase II trial of neoadjuvantpemetrexed plus cisplatin followed by extrapleural pneumonectomy and radiation for malignant pleural mesothelioma. J ClinOncol. 2009; 27: 3007-13. 
8. Datta A, Smith R, Fiorentino F, Treasure T. Surgery in the treatment of malignant pleural mesothelioma: recruitment into trials should be the default position. Thorax. 2014; 69: 194-7.

9. Taioli E, Wolf AS, Camacho-Rivera M, Flores RM. Women with malignant pleural mesothelioma have a threefold better survival rate than men. Ann Thorac Surg. 2014; 98:1020-4.

10. Espinoza MF, Berz D, Borgella JD, Imai TA, Soukiasian HJ. Neoadjuvant versus adjuvant chemotherapy for resectable malignant pleural mesothelioma: An analysis of the National Cancer Database. In.: American Society of Clinical Oncology; 2018.

11. Voigt SL, Raman V, Jawitz OK, et al. The Role of Neoadjuvant Chemotherapy in Patients with Resectable Malignant Pleural Mesothelioma - An
Institutional and National Analysis. J Natl Cancer Inst. 2020.

12. Sugarbaker DJ, Gill RR, Yeap BY, et al. Hyperthermic intraoperative pleural cisplatin chemotherapy extends interval to recurrence and survival among low-risk patients with malignant pleural mesothelioma undergoing surgical macroscopic complete resection. J ThoracCardiovasc Surg. 2013; 145: 955-63.

13. Gomez DR, Rimner A, Simone CB, et al. The Use of Radiation Therapy for the Treatment of Malignant Pleural Mesothelioma: Expert Opinion from the National Cancer Institute Thoracic Malignancy Steering Committee, International Association for the Study of Lung Cancer, and Mesothelioma Applied Research Foundation. J ThoracOncol. 2019; 14: 1172-83. 